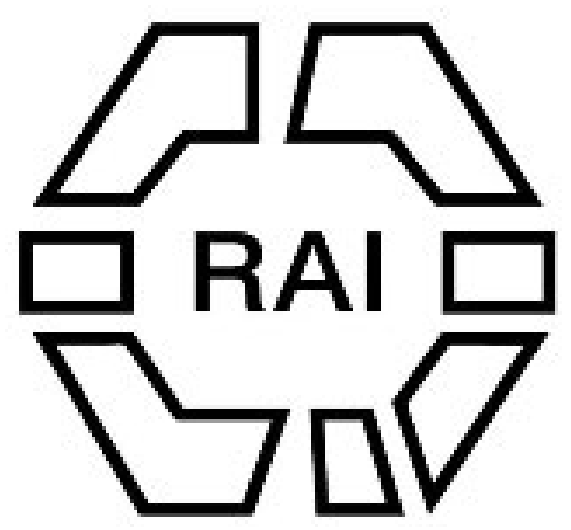

New Guinea

Author(s): Administrator of New Guinea

Source: The Tournal of the Anthropological Institute of Great Britain and Ireland, Vol. 21 (1892), pp. 481-487

Published by: Royal Anthropological Institute of Great Britain and Ireland

Stable URL: http://www.jstor.org/stable/2842442

Accessed: 14/06/2014 20:49

Your use of the JSTOR archive indicates your acceptance of the Terms \& Conditions of Use, available at http://www.jstor.org/page/info/about/policies/terms.jsp

JSTOR is a not-for-profit service that helps scholars, researchers, and students discover, use, and build upon a wide range of content in a trusted digital archive. We use information technology and tools to increase productivity and facilitate new forms of scholarship. For more information about JSTOR, please contact support@jstor.org.

Royal Anthropological Institute of Great Britain and Ireland is collaborating with JSTOR to digitize, preserve and extend access to The Journal of the Anthropological Institute of Great Britain and Ireland. 
poison is extracted is the bark of the roots and lower part of the stem. It is often employed without admixture and is then prepared as follows :-

The bark, which is burnt sienna coloured, is scraped with knives from the roots; the scrapings are put into a pan with water and boiled, the water is poured off and filtered. Fresh water is added to the bark, which is again boiled for some minutes, and the water poured off a second time. The exhausted shavings of bark are then thrown away, and the filtered infusion, which is bright burnt sienna coloured, is reduced by boiling in an open pan to a syrup. It is then poured while hot into a bamboo, where it solidifies. It is applied to the darts in the manner already explained and is said to be more powerful than the Antiaris, but is rendered quicker in its action when mixed with the poison derived from the other two plants above mentioned.

Of these prual is also a climber, growing on the hills. The largest stem $I$ have seen was $1 \frac{1}{2}$ inch in diameter. It has opposite bright green entire leaves, but its flowers and fruit I have neither seen nor been able to get any description of. The young shoots contain a very fine strong white, silky fibre. My specimens were also collected on Gunong Batu Puteh. The bark of the roots, which is rather pale yellow in colour, is the part of the plant which is employed in making the poison. This arrow poison is said not to be so strong as Antiaris, but to be quite capable of killing. when used by itself.

The third plant is called lampong and is also a climbing species of Strychnos. It has opposite, three-veined leaves like Ipoh aker only they are considerably smaller, and is stated to have similar fruit, but it grows lower down on the hills, my specimens being collected on the Cheroh hills. Like the two preceding plants, the bark of the roots, which is white, is the part from which the poison is extracted. It is said to be not so powerful as prual, but is often employed by itself,

In making the mixed poison six parts of scraped Ipoh aker bark are taken to which is added one part of each of prual and lampong bark and the mixture is exhausted with boiling water, filtered and evaporated in the same way as has already been described, when simple Ipoh aker is treated.

It was stated by the Sakias that Antiaris and Ipoh aker are rarely if ever mixed with one another. The latter poison is said to retain its virulence, in the form of an extract, for years.

\section{New Guinea,}

A despatch from the Administrator of New Guinea (No. 51), dated August 4th, 1891, contains the following :-

The impression produced on my mind by the Kiriwina (Latitude, $8^{\circ} 33^{\prime} \mathrm{S}$. ; Longitude, $151^{\circ} 4^{\prime} \mathrm{E}$.) people and country is a very favourable one; it does not appear to me that the population can 
be under 15,000-indeed it may be much in excess of that figure. In many ways they are a long step in advance of the natives on the north-east coast at the next place touched at, Collingwood Bay. In Kiriwina the position of chief is recognised and understood. They are industrious and well fed, and physically they are of superior build. The men all wear the pandanus leaf; the women short petticoats. Giriba and Vakuta seem to be noted places for the manufacture of those latter, especially the kind used for dancing purposes, which are dyed red, black, and white. The ordinary wearing petticoat is of simple undyed leaves; but women seldom came near me in those, but generally donned the dress petticoat, which is worn over the other. The dress petticoat is fastened on the hip for ordinary wear, but is tied in front for dancing. The men tattoo, but only slightly and in a rude way, but delight in ornamenting the bodies by small marks made by burning. The hair is usually worn long, but many hare the head shaved, except a small ruff of hair on the occiput. The men seldom wear shell ornaments, but many women have strings of red glass beads. I saw no trace of cannibalism. The outward signs of mourning for the dead are much insisted on. At Vakuta I saw two young widows in one village who wore as pendants from the neck the lower jaw of the deceased husband, richly ornamented with glass and shell beads. At another place a widow who had recently lost her husband, whose jaw was probably not yet prepared for wear, was deeply covered over with black, and had some half-dozen straps, about an inch and a-half broad, put round the body at intervals from the upper part of the chest to the hips. Young men, when they lose their mother, shave their heads and blacken the body until they have given the death feast, which puts an end to their season of mourning. After this is past, men sometimes wear one of the cervical vertebræ of the departed one tied into the hair of the head, as is seen occasionally in Milne Bay. They cook in pots of clay, which they obtain by trading from Murua, Kitiva, and elsewhere. The women seem to perform a considerable share of the work, but the men are by no means idle. On the whole, women have less influence and have much less to say than is the case in many of the ruder tribes on the mainland of New Guinea. This is apparently a consequence of the superior position of the chief in the Kiriwina social system. The men are skilful in the manufacture of fine wooden dishes and bowls in ebony and other hard wood, and their shields and spears are tastefully made. They do not appear to know either the sling (of such constant use in the neighbouring Goodenough Island) or the bow and arrow.

\section{The following notes are extracted from "The Annual Report on New Guinea, July, 1890 to 1891 ":-}

(p. 24.) Native Dialecrs.--Perhaps the most interesting of the seven vocabularies attached is that of the Dabu tongue, on 
account of its geographical position and the sharp lines of difference between it and the Kiwai-Mowatta language, and the dialect spoken at Saibai, Boiga, \&c. These latter dialects are given in last year's Annual Report. Many words in Dabu end in a consonant- $\mathrm{g}, \mathrm{l}, \mathrm{m}, \mathrm{n}, \mathrm{t}, \mathrm{p}, \mathrm{r}, \mathrm{k}$; and the $\mathrm{ng}$ is not uncommon. In this respect it more closely resembles the Saibai than the Kiwai language. It is just possible that the roots of a few Polyuesian words may exist in Dabu, as perhaps "papapi," butterfly (but the more common word is nipurigan, so that papapi may be introduced); "ngoi," cocoanut. But such words as those for boy, hand, cooking, pot, canoe, come, death, eye, hand, louse, mother, river, sago, \&c., seem to have no connection with the words which generally denote those objects over much of the Pacific and of the Possession east of the Gulf of Papua. So different are the coast languages on the west of the Papuan gulf from those east of it, that it seems improbable that the western dialects can have given rise to the eastern, or vice versâ. If they had a common origin, it must have been very remote.

In the Domara-Mairu dialect words are generally the same for, or are understood at, both places when they are printed only under one. The chief peculiarities of the Nada dialect will be found on p. 132. It is interesting as forming the language spoken at the extreme north-east corner of the Possession. It will be seen that Nala and Sinaugola have strong affinities to the central and eastern languages of the Possession, as well as to the Polynesian languages. It is somewhat surprising that Motu should differ so widely as it does from Toaripi, seeing that from time immemorial those tribes have traded with each other. In trading operations, however, they seem to use a jargon that is blended from both languages.

(p. 104.) Notes on the Laughlan Islands, By William TetzLaff. - The Laughlan group ${ }^{1}$ consists of seven small islands. The land is rery poor, so that with the exception of the cocoanut little else will thrive. The population is thus mostly dependent for their subsisience on fish and other marine produce. All of the islands are to a great extent covered by cocoanut trees, most of which are converted into copra, which is the principal article of trade on these islands, and wherein the natives are great experts. There are at present about sixty-two families, consisting of about 240 souls, distributed orer the group. T'here is no actual chief recognised by the whole of the population; but, as a rule, three or four families build together and choose one of the oldest men as the chief. There is also a house in each of the small villages set apart for the dead, also for the new-born.

The principal articles of diet are cocoanuts and fish. The latter are mostly caught with nets, or else dammed off and then aken when the tide recedes. There are also a few pigs kept on the islands, bat they are only killed at feasts or burials. Most of

1 (Lat. $9^{\circ} 20^{\prime}$ S.; Long. $153^{\circ} 3 i^{\prime}$ F.) 
their food is roasted or boiled. As the islands are fringed by numerous reefs, they are naturally the haunt of large lobsters, craytish, fish, shells, and other marine animals, of which they are very fond, and which constitute a large proportion of their diet. Of course this is only during fine or moderate weather : otherwise they devote the largest portion of their time to smoking and sleeping.

Yams, breadfruit, sweet potatoes, they trade from Woodlark Island $;^{1}$ they usually start from the end of November with the south-east, and return about the end of December with the northwest monsoons ; then there is a big feast for about fourteen days, in which time, as a rule, all the food brought over is consumed; then they return to their previous mode of living till the following year. T'he only break in their monotonous life is the arrival of a ship. There is always a great uproar in the community at a death of any of them, when all the people collect together and sing and cry all night. The corpse is brought to the dead house, and left there for five or six days. The nearest relations take watch and watch over the corpse; when it begins to putrefy, they wipe the sweat and other matter which oozes from the dead body, and smear themselres all over with it. As a rule, the body remains there until it is completely decomposed. Then the body is buried for over a month and then exhumed, and the head and all the bones carefully put together and buried in the bush.

Childbirth.- If a young woman is pregnant, she remains with her husband till labour begins, and then is removed to the place set apart for confinements. The young woman has then to drink a large quantity of water bespoken by the sorcerer; then they believe that labonr will be modified to a great extent. During all this time she is strictly watched by her relations and friends. When the confinement is about to take place, a part of a cocoanut tree is brought, and the woman has to sit on it, and birth takes place in the usual course. Sometimes it does happen though that the mother suffers great pain, and it does not unfrequently happen that the mother kills the child on these occasions. The people surrounding her show little or no sympathy with either; but should everything have gone off satisfactorily, the woman has to remain about eight days in the house till the navel string is dried up. Then they make a large fire round the house, which almost suffocates both mother and infant. After this all the relations of both husband and wife gather together and bring presents; then the feasts begin and continue for two days. The husband comes to the house, and the couple are rubbed well over with cocoanut oil, and then deck themselves with native ornaments and beads, and then are presented to the gathering. Of course this only takes place on the occasion of the first-born, as the eldest always takes his father's place at his death. Sometimes it happens also that single girls get enceinte; then they often resort to abortion.

${ }^{1}$ (Lat. $9^{\circ} 5^{\prime}$ S. ; Long. $152^{\circ} 46^{\prime}$ E.) 
This is done in the following manner:-The girl goes to her mother, or some other old woman who practises witchcraft. The girl has to lie on her back, and the woman presses in the dircction of the womb till it almost gives a loud report (sic), whien, as a rule, the child is killed. This practice is not only done by single girls, but by young married women also, who dread the pains connected with child-birth.

Classification OF Natives.-As there are seven different islands so there are also seven different communities, which they call Kuhms; they consist of the following:-1, Meres; 2 , Schnauis ; 3, Lekusis ; 4, Kumuro ; 5, Kunithau ; 6, Fretock ; 7, Labes. If ever a disturbance occurs, which not unfrequently happens between two or three of the villages, the others louk on or make peace. In marriage they seldom or never marry in their own village, but from any of the other of the six villages. 'The father has nothing whatever to do with the children; they belong: to the mother. Should the father die, all his belongings, such as cocoanut trees, \&c., go to his relations ; the children or mother get nothing. Should the mother die, the chilaren and relatives divide while the husband gets nothing. The same law holds good for Woodlark Island and for the Trobriands (Lat. $8^{\circ} 35^{\prime} \mathrm{S}$. ; Lon. $141^{\circ} 0^{\prime}$ E.). Similar to civilised people, the Laughlan islanders believe in a future state. They also believe the spirits of their deceased friends or relations go to Wartheum, a small island in the Trobriands Group. This is supposed to be the native paradise, as they have no work to do, only eat, drink, and sleep, which seem to be the things most appreciated by them. There is also supposed to live an old woman in Wamana, another small island, who is said to sleep six days out of seven. Sometimes she goes to Wartheum to visit her parents. When she returns to the Laughlan Islands she often describes how pretty it is there, and she wished to remain in Wartheum; but her parents would not allow her, and tell her to return to her husband and family.

SPORTs.-In the time when most of the canoes leave for Woodlark Island those left behind-principally the women-devote their time to various amusements. The principal of these is to make a great sandhill on the beach in the moonlight; then they sit on it and sing and defy the men to pull them off.

At first the latter do not respond, but by-and-by they appear one by one, and make a similar sandhill. Of course the numbers must be equal on either side; then both sides begin to sing; suddenly one of the men makes a dash and seizes one of the women, then all her companions try to rescue her; the men also go to assist their side. A general wrestling then begins, which usually ends in someone being more or less seriously injured. This amusement from a European point of view is not very interesting, but seems to be the favourite pastime.

SEA-WATER.- Sea-water seems to play a great part in the preparation of their food, as they do not understand the mode of extracting the salt from the water. They also use it as aperient 
medicine, \&c. The stomach seems to be the seat of all ailments. For instance, if the husband and wife have a slight discussion, both of them have to drink salt water until their dispute is settled, \&c. When a woman is enceinte she is also to drink a large quantity of it, as it is supposed to strengthen the child. No one is believed to die a natural death unless he is killed; if one should die through sickness he is certainly supposed to have been bewitched, and mostly the old women are credited with it, as they are supposed to enter the body and bite the intestines with their teeth, or else put a stone in the stomach. Should one get seriously sick all the friends and relations meet together and make an infernal noise to drive away the evil spirit. On these occasions the dogs and children join in, while the men throw spears in all directions, and the sick man goes " bung." They are also very superstitious as regards dreams; what they dream of at night they firmly believe will take place. They are very frightened of death in spite of the happy times held out to them at Wartheum. Should anyone have toothache or headache he has to hold a piece of tortoise shell in his mouth until he is relieved. Stomach-aches and headaches are also supposed to come from the stomach; in those cases an old woman is generally called in to extract the stone. The first proceeding is to chew betel nut, the next to pass a charm over the spot; then the old woman gently passes her hand over the painful part, and usually on the third or. fourth movement a stone falls from her hand. To expose this has been a difficult matter, as no one was willing to come forward to dispute it.

THE Moon.-The moon was formerly part of the earth, and is at present considered to be an old woman; the stars are also bad old women to whom admittance to Wartheum has been refused, and whose punishment it is to watch the moon. In olden times the woman used to keep the moon in a basket and guard it very jealously, even from her children; then when she went out at night she opened the basket and by the moonlight was guided on her visits to Wartheum. As long as the children were small all went well, but as they grew up her disappearance at night and the light, following her roused their suspicion. They watched and saw how the mother put the moon ("debukou.") in her basket. They then spoke to the mother about the light and asked her to let them see it. She at once got very angry, and told them not to inquire into it any further; but as they persisted she suddenly rose in the air, since which time all nations have a moon. The stars are supposed to watch the moon so that the old woman is unable to replace it in her basket; otherwise they would have no moonlight for their singing and dancing. Whenever they see a shooting star they make a great noise, as they believe that it is the old woman who keeps the moon come down to the earth to catch somebody to take her place so that she might go to Wartheum.

Frre. - In olden times there were seven old women living at Woodlark Island in harmony. They used to till their gardens and live a happy lifo; the only drawkack they had was the want of 
fire, in consequence of which they suffered greatly from ulcers and sores, as they had to eat their food raw; but one of them knew the secret of making fire, which kept her in good health, as she was able to cook her food; for a long time she kept her secret from the others, but eventually they fousd out and got very angry with her and left her. They said, "you are greedy "schmaui.", The others then left Woodlark Island and settled on the Laughlans, each of which islands bear their names, viz., Meres, Lekusis, Komoro, Kunithau, Tretock, and Labes. It is also the habit to give young boys the head of a snake to eat, to make them brave and fearless in warfare.

Aboriginal dialects of Bula's, Domara-Mairu, Dabu, Nada, Nala, Sinaugolo, and Toaripi are given, the system of orthography being that adopted by the Royal Geographical Society, \&c.

\section{"Scierce in Plain Language. Evolution, Astronomy,} Food, Physiology, \&c." By William Durham, F.R.S.E. (Adam and Charles Black, 1891.) 8vo. pp. 123. The author in the preface states that the work is intended for " intelligent and thoughtful people who have not the time, nor perhaps the inclination to read regular scientific works, but who neveruheless would be glad to know the general results of scientific investigation if that knowledge could be imparted to them in plain every-day language without too much detail." 'The scheme of the work is well carried out, the priricipal articles being on natural selection, protoplasm, colour, movement, the sun and moon, the earth, stars, nebulæ, \&c., planets, astronomical speculations, tides \&c., focds, and physiology.

\section{"Illegitimacy and the Influence of Seasons upon conduct."}

By Albert Leffingwell, M.D. (Swan Sonnenschein, 1892.) 8 vo. pp. 160. The volnme contains two essays, the first is devoted to a consideration of illegitimate births in the different sections of the British Isles, the second being an attempt to present to the reader certain phenomena of periodicity in human conduct and mental disease, which, although for many years familiar to students, are still comparatively unknown to the general public. The work contains a large amount of statistics, and the coloured diagrams appear to have been very carefully prepared. On page 12 a table is given, "Of each thousand children born in England, Scotland, and Ireland, how many were illegitimate?" The numbers for 1889, were:-Ireland 28 , England 46, Scotland 79.

"The Faiths of the Peoples." By J. Fitzgerald Molloy. (London: Ward and Downey, 1892.) 2 vols., 8 vo., pp. vi, 251; $\mathrm{vi}, 218$. In this work, which is unfortunately controversial in tone, Mr. Moiloy describes visits to some seventeen out of the two hundred and odd places of worship on the list of the RegistrarGeneral. Judaism, The Children of Islam, The Irvingites, The Southcottians, and the Comtists are amongst those sects described in the first volume; while in the second volume, the author records 